\title{
THE ADAPTATION OF INDOOR HEALTH AND COMFORT CRITERIA TO MITIGATE COVID-19 TRANSMISSION IN THE WORKPLACE
}

\author{
Dyah Kusuma Wardhani ${ }^{1 *}$; Susan ${ }^{2}$ \\ ${ }^{1,2}$ Program Studi Arsitektur Interior, Fakultas Industri Kreatif, Universitas Ciputra \\ Citraland CBD Boulevard, Made, Surabaya, Jawa Tengah 60219, Indonesia \\ 1dyah.wardhani@ciputra.ac.id; ${ }^{2}$ susan@ciputra.ac.id
}

Received: $23^{\text {th }}$ October 2020/ Revised: $14^{\text {th }}$ December 2020/ Accepted: $15^{\text {th }}$ December 2020

\begin{abstract}
How to Cite: Wardhani, D. K., \& Susan. (2021). The adaptation of indoor health and comfort criteria to mitigate Covid-19 transmission in the workplace. Humaniora, 12(1), 29-38.

https://doi.org/10.21512/humaniora.v12i1.6767
\end{abstract}

\begin{abstract}
The research discussed the application of indoor health and comfort criteria that needed to be reviewed to create good indoor environmental quality and reduce the transmission of the Covid-19 virus where people spent most of their time indoors. A confined area, which was poorly ventilated and reliant on air conditioning, helped transmit the Covid-19 virus easily as air recirculation was the main cause of office clusters. One of the categories of Greenship Interior Space, Indoor Health and Comfort (IHC), could be used as a guide for creating better indoor quality. The method used for the research was a systematic literature review to define, study, analyze, and classify all available research relating to adaptation of indoor health and comfort criteria to mitigate the transmission in the workplace. The results show the adjustment to IHC criteria in IHC 1-10, which focus on providing good air quality by introducing outside air, stopping air recirculation, reducing indoor user capacity, and reducing indoor biological and chemical pollutants. To illustrate the implementation of the new normal, Ciputra University workplace was being observed, as the findings of the results, some strategies that are in line with the objectives of IHC 1, IHC 2, and IHC 5. Adjustment of these criteria must be supported by implementing health protocols through basic hygiene routines, fitness screening, and maintaining physical distancing.
\end{abstract}

Keywords: indoor health, comfort criteria, Covid-19 mitigation, Covid-19 transmission

\section{INTRODUCTION}

Coronavirus (Covid-19) is a contagious disease that has impacted globally in the last few decades (Morawska \& Cao, 2020). Until now, there is no cure for this disease, so the only way to fight this virus is to prevent transmission virus through daily hygiene and isolation of infected people. The WHO statement about Covid-19 can spread through microdroplets or aerosols, emphasizing the importance of wearing masks as the most effective way to prevent transmission. Apart from wearing masks, proper ventilation is needed to minimize the spread of Covid-19 through the air.

The current pandemic focused on good air quality indoors can minimize virus transmission. Instead of encouraging health and well-being, it has developed conditions that also degrade air quality with poor ventilation, recirculation of air, material requirements, and additional emissions from mechanical heating and cooling. The enclosed space with a poor ventilated environment and air conditioning help to spread the Covid-19 virus rapidly due to the air recirculation that has also caused office clusters to appear. Based on the Health Office data as of August 2020, there are 1081 office clusters in DKI Jakarta and 54 closed offices.

The Covid-19 pandemic underlines the relevance of the atmosphere to wellbeing. Since people do most of their activities inside the building, the quality of indoors can affect their health. It impacts human health across several causes, such as indoor pollutants, contaminants on the surface, and interaction between people. Creating good indoor environmental quality is critical for spatial planning during this pandemic. The health and indoor comfort category 
from Greenship Interior Space is one of the categories that can be used as a reference for creating good indoor environmental quality. By applying this green building principle, it provides better lighting quality, ventilation, and $\mathrm{O}_{2}$, and Volatile Organic Compound (VOC) concentrations in space (Lim et al., 2012). Due to the Covid-19 pandemic, the application of indoor health and comfort criteria needs to be reviewed. Creating good indoor environmental quality can also reduce the transmission of the Covid-19 virus. The research needs to be done because there is still a lack of research to determine the adjustment of the Indoor Health and Comfort criteria in Greenship Interior Space to mitigate the transmission of Covid-19 in the workplace. Several previous researches has discussed buildings that are LEED (Leadership in Energy and Environmental Design)-certified (Lee \& Guerin, 2010), infection prevention for Covid-19 patients (World Health Organization, 2020), the connection of coronavirus with respiration ( $\mathrm{Wu}$ et al., 2020), the role of the air conditioning system in infection prevention (Sundari et al., 2018), assessment of IHC (Wardhani \& Susan, 2019), and how to optimize indoor health and comfort (Susan \& Wardhani, 2019).

For the workers, the pandemic has made health and safety an increasingly personal issue because it is not only about protection for themselves but also protection for their families and social circles. The conditions of the Covid-19 pandemic have made people rethink the buildings and space they live in by posing new possibilities through required changes, especially for users' health and comfort. It is an opportunity to reduce the spread of the Covid-19 virus in the workplace by providing a better and healthier work environment. The research presents a proposal for adjusting the criteria for the indoor health and comfort category on the Greenship Interior Space parameter for space so that it not only contributes to user health and comfort but also reduces the spread of the Covid-19 virus.

\section{METHODS}

The method applied in the research is a Systematic Literature Review (SLR) method. The SLR approach is used to define, study, analyze, and classify all available research relating to the phenomenon of interest with applicable particular research concerns. A systematic analysis and identification of articles can be carried out using the SLR method. (Triandini et al., 2019). Figure 1 shows the steps in the systematic literature review.

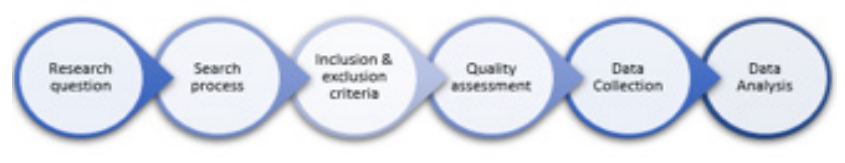

Figure 1 Steps in Systematic Literature Review (Source: Personal Documentation)
The first step in this method is to define the research question, how are the indoor health and comfort criteria need to be adjusted to mitigate the transmission of Covid-19 in the workplace. After defining the research question, the search process begins to get relevant sources to answer research questions with keywords: Covid-19, airborne transmission, office cluster, indoor air quality, indoor environment, and new normal. After collecting the data through the search process, the data are selected with inclusion and exclusion criteria to ensure the data found is suitable for the research. For inclusion and exclusion criteria, the data are selected to check the eligibility. The eligibility criteria of the data are the data used in the range of 2010-2020, data obtained through https://www.sciencedirect.com/ as primary data, https://scholar.google.co.id/ as secondary data, and only data related with the research question are used.

The quality assessment of the data is based on the research question and the inclusion and exclusion criteria. The data collection is compiled with Mendeley software, and then it is analyzed to show that adjustments need to be made to the IHC criteria that can be used to create good indoor environmental quality and mitigate the transmission of Covid-19. By performing a comprehensive literature search, changes are made to the IHC criteria in Greenship Interior Space that can be adapted in the workplace to mitigate the spread of the coronavirus.

\section{RESULTS AND DISCUSSIONS}

Most people do $70-90 \%$ of their activities indoors (Darus, Ahmed, \& Latif, 2011). Indoor environmental quality plays an important role in daily lives, especially during a pandemic when the duration of people indoors takes more time than before because of lockdown. Greenship Interior Space is one of the parameters that can be used as a rating system to provide better indoor quality. Issued by Green Building Council Indonesia, Greenship Interior Space consists of several categories ASD (Appropriate Site Development), WAC (Water Conservation), MRC (Material Resources and Cycle), EEC (Energy Efficiency and Conservation, BEM (Building Environment Management), and IHC (Indoor Health and Comfort). Each category percentage can be described in Figure 2.

IHC category has the highest percentage in the rating tools because indoor health and comfort play an important role in the occupant's health and comfort. IHC is an analysis instrument used to establish a highquality indoor space for the health and comfort of its inhabitants with 11 criteria. It can be explained in Table 1.

As it can be seen from Table 1, there are three types of credit: prerequisite $(\mathrm{P})$, credit criteria, and bonus (B). Greenship Interior Space is not only about the space but also about the buildings and surroundings that have been chosen to be occupied. Prerequisite 


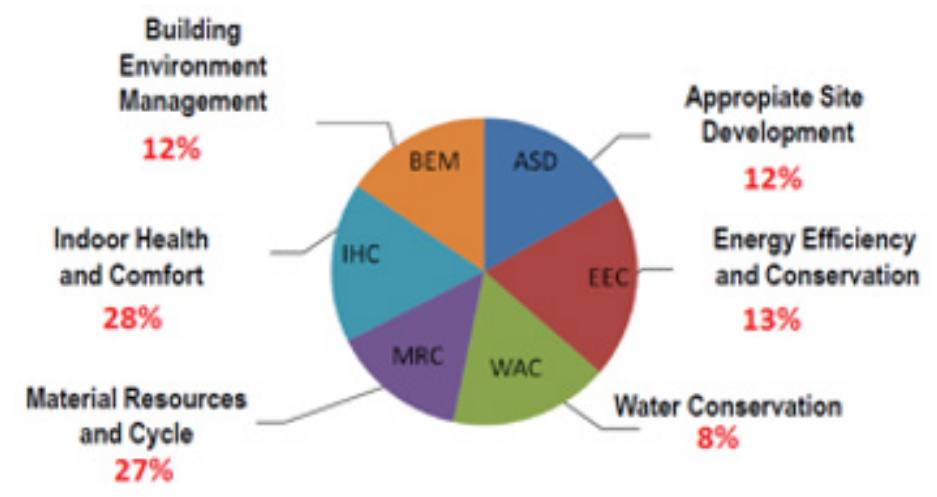

Figure 2 Credit Percentage in Greenship Interior Space

(Source: Nasir, 2012)

Table 1 Indoor Health and Comfort Criteria

\begin{tabular}{clc}
\hline Code & \multicolumn{1}{c}{ Criteria } & Credits \\
\hline IHC P & No Smoking Campaign & P \\
IHC 1 & Outdoor Air Introduction & 1 \\
IHC 2 & CO 2 Monitoring & 2 \\
IHC 3 & Chemical Pollutant & 9 \\
IHC 4 & Indoor Pollutant Source Control & 2 \\
IHC 5 & Biological Pollutant & 1 \\
IHC 6 & Visual Comfort & 3 \\
IHC 7 & Outside View and Daylight & 2 \\
IHC 8 & Thermal Comfort & $2(+2 B)$ \\
IHC 9 & Acoustic Level & 1 \\
IHC 10 & Interior Plants & 2 \\
IHC 11 & Pest Management & 1 \\
\hline
\end{tabular}

(Source: Nasir, 2012)

criteria are criteria that exist in each category and must be met with the criteria. If one of the conditions does not meet, the credit criteria and bonus criteria in all Greenship categories cannot be accepted. This prerequisite criterion has no value but mandatory to be fulfilled. Credit criteria are criteria that exist in each category and can be selected to collect the score. The fulfillment of these criteria is related to the capabilities of the interior space. If the credit criteria are met, then the interior of the space assessment will get a score. Bonus criteria are criteria that only exist in certain categories that allow providing additional value. This criterion can be chosen whenever possible and will be a bonus value because the condition for the bonus is quite difficult and rarely occurs in the field. Therefore, buildings that can meet the criteria have their own prestige.

Before discussing the adjustment needed for indoor health and comfort criteria to mitigate the Covid-19 virus, it must be known about the virus transmission. So far, there is no cure for the disease yet, and to flatten the curve, the only way is by reducing transmission, especially in a workplace as a meeting point for several people. The strategy for reducing Covid-19 transmission is isolating infected people and tracing people who interact with them (Khanna et al., 2020). Transmission between people happens in 2-10-day virus incubation by droplets, infected hands, and surfaces. Human coronavirus can remain infectious at room temperature can stay nine days on inanimate materials (Kampf et al., 2020). The minimum suggested distance is two-meter to minimize the possibility of transmission by droplets (Setti et al., 2020).

A World Health Organization (World Health Organization, 2020) review of patients tested that infectious disease can be transmitted over an environmentally relevant by aerosols (e.g., airborne infection) and can result in large batches of infections in a short period of time. The details available on the transmission of the Covid-19 virus confirm the theory of an airborne spread of droplets from the infectious subject with a distance of more than two meters. An interpersonal gap of two meters can only be said to 
be adequate security if someone uses a mask in their everyday activities (Setti et al., 2020). Coughing can release about 3.000 droplets when sneezing releases about 40.000 droplets (Dhand \& Li, 2020) that are mainly tiny droplets $(1-10 \mu \mathrm{m})$. As infected subjects breathe, $80-90 \%$ of droplet sizes $<1 \mu \mathrm{m}$ are aerosol transport (Morawska et al., 2009). Breathing and talking have a role in the spread of the virus, particularly in asymptomatic cases. This virus transmission can be seen in Figure 3.

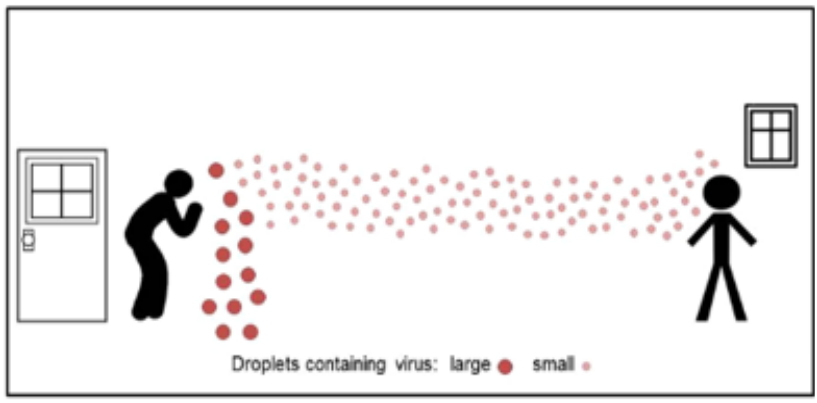

Figure 3 Droplets and Aerosol Transmission (Source: Morawska \& Cao, 2020)

The probability of indoor transmission can increase due to crowded places, duration and vocalization, and inadequate fresh air or ventilation (Morawska et al., 2020). When it comes to mitigating the spread of virus indoor, the priority should be paid to building features that ensure improved levels of airflow, appropriate air circulation, and a system of piping that reduce the risk of viral aerosol (Gormley, Aspray, \& Kelly, 2020; Morawska et al., 2020; Wu et al., 2020). This statement also explains the emergence of many office clusters, especially in offices in the form of enclosed space with insufficient ventilation and lack of fresh air, full capacity layout, and long working hours.

Over the pandemic, many workplaces cease working and force employees to operate from home due to social distancing. After the office begins to operate gradually, certain changes need to be made to protect employees at the workplace as the possibility of transmission rises, particularly in offices with closed areas where social distances are difficult. Business management who strategically develops preventive plans to mitigate the risk of Covid-19 spread can decrease the pandemic and ensure workers' well-being. It can become a bright light for offices to continue to operate in this tough time. Adapting the criteria of IHC to create better indoor space can be one solution in reducing Covid-19 transmission indoor.

Based on the literature review, the suggestion for adaptation of indoor health and comfort criteria can be applied in the workplace to reduce the transmission of Covid-19. Well-designed ventilation, the filtration of the air, relative humidity, and temperature are the main techniques that can be used as a strategy to improve air quality. Appropriate ventilation and minimization of air recirculation inside a building is a fundamental way to reduce airborne virus transmission (Brittain, Wood, \& Kumar, 2020). Ventilation, open spaces, good usage, and regular disinfection of toilets can effectively mitigate the airborne transmission of Covid-19 (Morawska et al., 2020). Details of the adjustment in indoor health and comfort criteria can be explained in Table 2 .

Table 2 Adaptation of Indoor Health and Comfort Criteria

\begin{tabular}{ccl}
\hline Code & \multicolumn{1}{c}{ Criteria } & \multicolumn{1}{c}{ Adaptation Strategy } \\
\hline IHC P & No Smoking Campaign & $\begin{array}{l}\text { No smoking campaign still needs to be implemented to provide clean air for } \\
\text { the indoor environment. }\end{array}$ \\
& & \\
IHC 1 & Outdoor Air Introduction & Proper ventilation can remove viral aerosols in a short time (Cook, 2020) \\
& & - Well-designed natural ventilation \\
& & - Increasing outdoor air exchange rates \& the inflow of outdoor air. \\
& & - Stop air recirculation \\
& & $($ Tang et al., 2020)
\end{tabular}

Recirculation of central air conditioning which covers several zones should be avoided. Shut the recirculation damper and open the outdoor air damper to maximize the outdoor air rate and use the germicidal ultraviolet to eliminate contaminants from the recirculated air.

In the case of split air conditioning units, potential contamination by air should be avoided where possible. Additional ventilation should be available through a window opening or other mechanical ventilation where necessary for cooling. (Morawska et al., 2020).

Also, air recirculation can increase human exposure to viral aerosols released by other building users. Building management must be able to consider which one is more optimal to apply into the building, whether by increasing the introduction of outside air or by increasing the air exchange rates (Dietz et al., 2020). 
Table 2 Adaptation of Indoor Health and Comfort Criteria (Continued)

\begin{tabular}{|c|c|c|}
\hline Code & Criteria & Adaptation Strategy \\
\hline \multirow[t]{3}{*}{ IHC 2} & $\mathrm{CO}_{2}$ Monitoring & Avoid crowded and poorly ventilated spaces (Tang et al., 2020). \\
\hline & & Limit the number of people to $50 \%$ in closed spaces (Morawska et al., 2020). \\
\hline & & $\begin{array}{l}\text { A space with high occupancy and activity traffic increases social interaction and } \\
\text { the possibility of direct transmissions of Covid-19 from people to people and } \\
\text { people with contaminated surfaces (Dietz et al., 2020). }\end{array}$ \\
\hline \multirow[t]{2}{*}{ IHC 3} & Chemical Pollutant & $\begin{array}{l}\text { There evidence of survival of Covid-19 virus stay more than three days on } \\
\text { plastic and stainless steel (Brittain, Wood, \& Kumar, 2020) }\end{array}$ \\
\hline & & $\begin{array}{l}\text { Antimicrobial agents, such as copper alloys, help to eliminate or prevent } \\
\text { pathogens growth that can be applied for frequent contact surfaces (Brittain, } \\
\text { Wood, \& Kumar, 2020) }\end{array}$ \\
\hline $\mathrm{IHC} 4$ & $\begin{array}{l}\text { Indoor Pollutant Source } \\
\text { Control }\end{array}$ & $\begin{array}{l}\text { The criteria still need to be implemented for a better indoor environmental } \\
\text { quality with minimum indoor pollutant source. }\end{array}$ \\
\hline \multirow[t]{5}{*}{ IHC 5} & Biological Pollutant & $\begin{array}{l}\text { Antimicrobial agents, such as copper alloys, helps to eliminate or prevent } \\
\text { pathogens growth that can be applied for frequent contact surfaces (Tang et al., } \\
\text { 2020). }\end{array}$ \\
\hline & & $\begin{array}{l}\text { UV light, ionization units, or HEPA filter can be used for air purification to } \\
\text { efficiently minimize the accumulation of infectious viral aerosols (Tang et al., } \\
\text { 2020). }\end{array}$ \\
\hline & & $\begin{array}{l}\text { HEPA filters can filter } 99,97 \% \text { of particles up to } 0,3 \mu \mathrm{m} \text { in size. Most viruses, } \\
\text { including the Covid virus, range from } 0,004 \text { to } 1,0 \mathrm{um} \text {, limiting the effectiveness } \\
\text { of filtration techniques against viruses such as Covid-19 (Dietz et al., 2020). }\end{array}$ \\
\hline & & $\begin{array}{l}\text { UV Germicidal Irradiation (UVGI) gives risk to the occupant's health when } \\
\text { exposed directly to high-energy light. The UVGI installation can be applied to } \\
\text { the top of the room in the ventilation path. UVC light on the } 207 \text { to } 222 \mathrm{~nm} \\
\text { range has been shown to effectively eliminate aerosol viruses (Miller, Linnes, } \\
\text { \& Luongo, 2013). }\end{array}$ \\
\hline & & $\begin{array}{l}\text { In places with a lack of openings, the installation of air filtering or disinfection } \\
\text { equipment, for example UV light germicidal can be advantageous (Kumar \& } \\
\text { Morawska, 2019). }\end{array}$ \\
\hline IHC 6 & Visual Comfort & $\begin{array}{l}\text { Visual comfort still needs to be implemented for a better indoor environmental } \\
\text { quality and keeps the worker productivity, especially the importance of daylight } \\
\text { that helps human metabolism. }\end{array}$ \\
\hline \multirow[t]{2}{*}{ IHC 7} & Outside View and Daylight & $\begin{array}{l}\text { Outside view and daylight are important to be implemented, as natural light } \\
\text { provide vitamin D that helps human metabolism (Salingaros, 2015). }\end{array}$ \\
\hline & & $\begin{array}{l}\text { Daylight is a strategy to control the viability of infectious disease viruses in } \\
\text { the room. Daylight is an important element in architecture and related with } \\
\text { the presence of bacteria and pathogens, especially their growth in dark spaces. } \\
\text { The number of microbes is related to the dust in the room in an interior space } \\
\text { (Fahimipour et al., 2018). }\end{array}$ \\
\hline \multirow[t]{3}{*}{ IHC 8} & Thermal Comfort & $\begin{array}{l}\text { Many air conditioning settings focus on the occupants comfort, but not } \\
\text { considering contaminants growth control (Tang et al., 2020). }\end{array}$ \\
\hline & & $\begin{array}{l}\text { Keeping indoor relative humidity above } 40 \% \text { will significantly reduce the } \\
\text { effectiveness of transmission aerosol viruses. Recommended RH between } 40 \% \\
\text { and } 60 \% \text { indoors to reduce the spread of the Covid- } 19 \text { virus and minimize the } \\
\text { risk of mold growth (Noti et al., 2013; Rousseau et al., 2017) }\end{array}$ \\
\hline & & $\begin{array}{l}\text { USEPA suggests to keep the RH to } 30 \%-50 \% \text { RH, a range that not only } \\
\text { appropriate for thermal comfort but also reduces the mold growth (EPA, 2009). }\end{array}$ \\
\hline IHC 9 & Acoustic Level & $\begin{array}{l}\text { Acoustic level still needs to be implemented regarding noise level in the } \\
\text { workplace and reduce the noise that creates viral aerosol. }\end{array}$ \\
\hline IHC 10 & Interior Plants & $\begin{array}{l}\text { Further research is required to decide if indoor landscaping affects indoor air } \\
\text { quality. }\end{array}$ \\
\hline
\end{tabular}


Table 2 Adaptation of Indoor Health and Comfort Criteria (Continued)

\begin{tabular}{|c|c|c|}
\hline Code & Criteria & Adaptation Strategy \\
\hline & & $\begin{array}{l}\text { Green wall integrated with the architecture will have a beneficial impact on the } \\
\text { quality of indoor space and improve the indoor health index (Kazemi, Rabbani, } \\
\text { \& Jozay, 2020). }\end{array}$ \\
\hline & & $\begin{array}{l}\text { The use of potted plants start to affect on indoor air quality when one plant is } \\
\text { used per } \mathrm{m}^{2} \text { (Cummings \& Waring, 2020). }\end{array}$ \\
\hline IHC 11 & Pest Management & $\begin{array}{l}\text { Pest management still needs to be implemented to reduce the biological } \\
\text { pollutants that come from pest. }\end{array}$ \\
\hline
\end{tabular}

From the adaptation of the criteria for IHC, then it is used as a guide to observing the application of the new normal in the office area at Ciputra University as a case study. Adjustments in the office space layout are made by reducing the number of staff working at the office in shift system, the room capacity is reduced up to $50 \%$, and all meetings are held virtually. It can be seen in Figure 4.

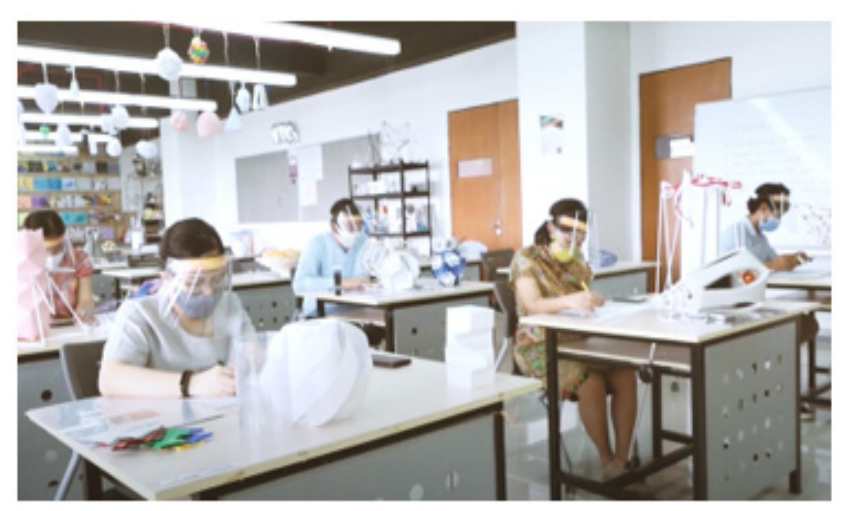

Figure 4 Working in Shift

(Source: Personal Documentation, 2020)

Each office area generally uses split air conditioners, but in the pandemic, the windows are also opened to let the outdoor air enter inside the room. From these conditions, the IHC 1 criteria have been considered as an attempt to include outside air and IHC 2 to reduce $\mathrm{CO}_{2}$ levels by reducing the capacity of indoor users by up to $50 \%$. Adjustments to the workstation layout can also be made by giving each worker a distance of 2 meters with a zig-zag pattern, as shown in Figure 5.

Human behavior also plays an important role in the process of Covid-19 transmission. Behavior changes in the form of implementing health protocols as a general rule can prevent transmission if there is no medical intervention yet (West et al., 2020). In addition to adjusting the criteria for IHC, it is also necessary to carry out health protocols in the office (Marshall et al., 2020), as described as follows; basic hygiene routines, frequent disinfection, fitness screening, social distancing, workplace flexibility, and reducing face to face meetings.

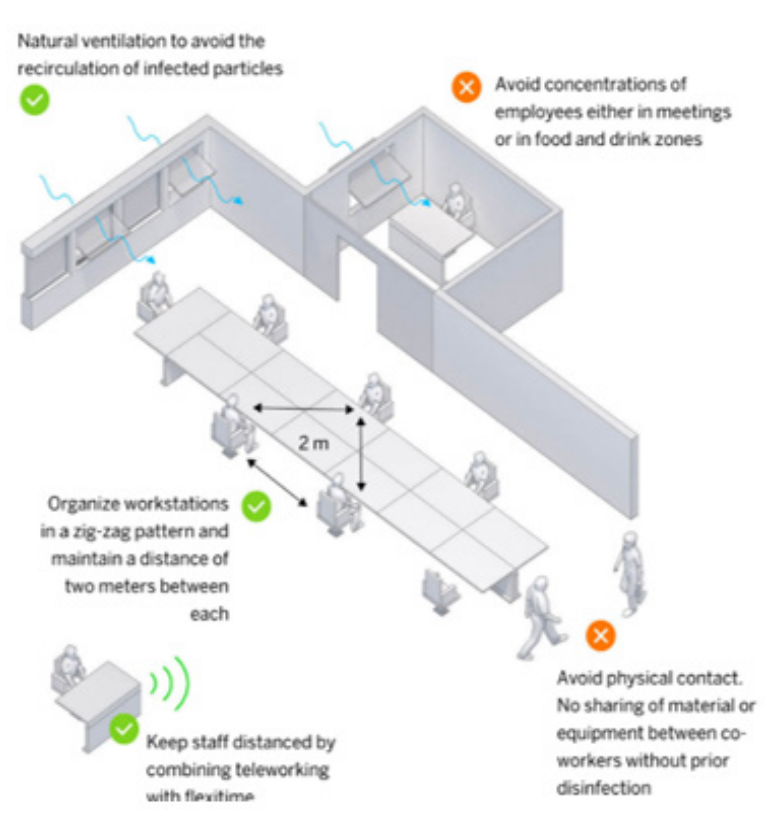

Figure 5 Alternative Workstation Layout Arrangement (Source: Salas \& Zafra, 2020)

Several health protocols have been implemented to help reduce biological pollutants in IHC 5 criteria through the application of basic hygiene routines by creating a habit of washing hands, providing soap and running water at several spots in the workplace, particularly in the area before the entrance (Figure 6). It is recommended to wash hands regularly and thoroughly. Besides water and soap, hand sanitizers can be used with an alcohol level of at least $60 \%$ that put in the workplace at several spots (Figure 7). Providing facial masks for all workers and mandatory to use in the office, visitors are also expected to follow the same health policy.

Frequent disinfection is part of the procedure to reduce infection in the workplace by performing routine disinfection and cleaning frequent contact surfaces and appliances (Figure 8). Cleaning is done twice before and after working. The cleaning materials used must also be environmentally friendly to harm the environment due to frequent cleaning.

Fitness screening is also done, such as temperature checks, checklists of symptoms, and history of the exposure. Routine rapid and swab testing 
are also required to track possible transmission causes and isolate them before symptoms occur. In particular, regular testing is required for this testing technique, particularly for high-risk and high-traffic workplaces where employees have frequent encounters and social distances could not be applied. When any person has signs and symptoms of illness, a procedure must be in action at the workplace to isolate and examine the person. A protected space to cover potentially infected staff before they can be safely removed from work by health personnel. Other efforts to avoid the transmission can also be made, such as using the touchless lift buttons and thermal screening camera shown in Figures 9 and 10.
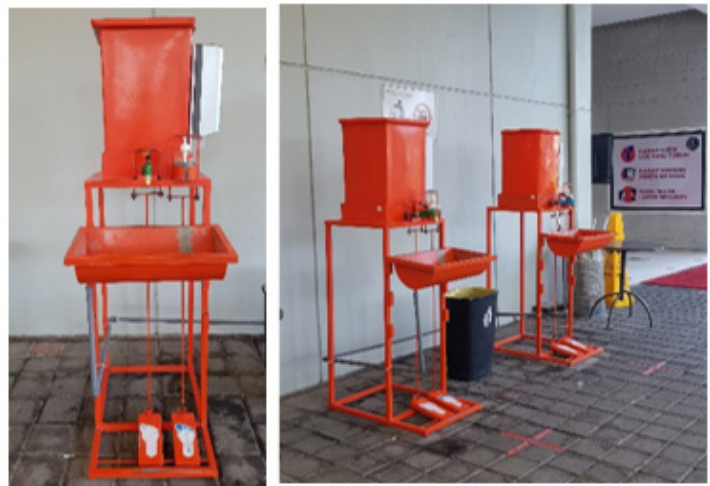

Figure 6 Hand Washing Area at the Entrance (Source: Personal Documentation, 2020)

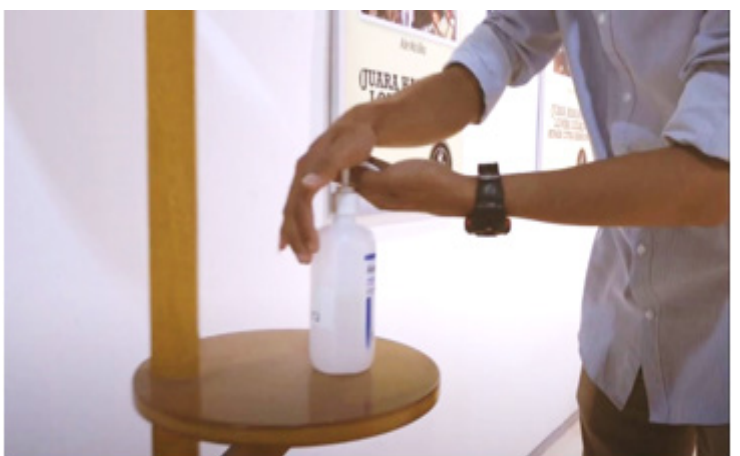

Figure 7 Hand Sanitizers at Several Spots in the Workplace (Source: Personal Documentation, 2020)

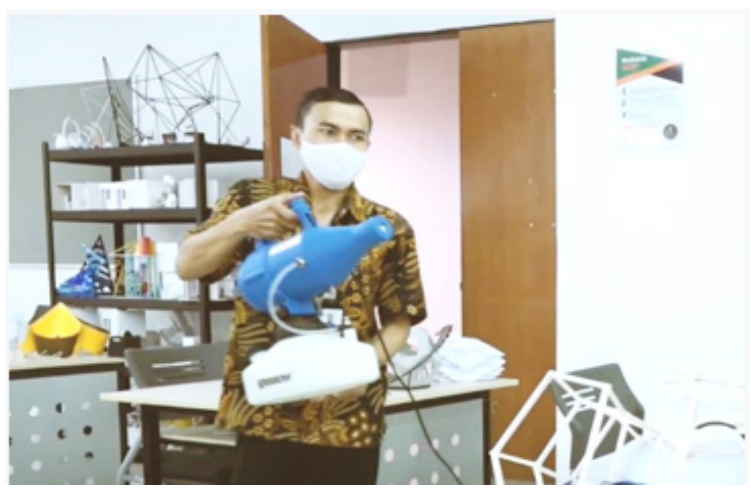

Figure 8 Frequent Disinfection (Source : personal documentation, 2020)
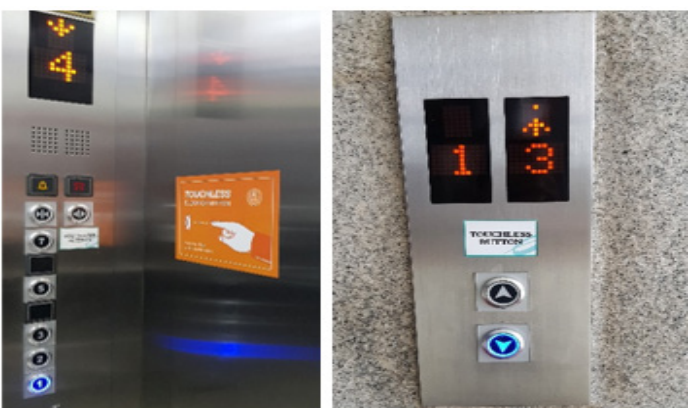

Figure 9 Touchless Lift Buttons to Minimize Contact (Source: Personal Documentation, 2020)

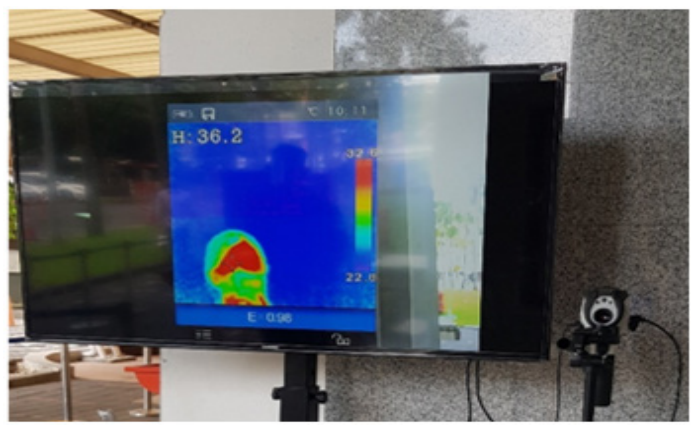

Figure 10 Thermal Screening Camera

(Source: Personal Documentation, 2020)

Social distancing is maintaining the distance between the workers, especially in an open office where contacts are frequent. The spatial configuration of buildings can affect social interaction patterns that occur, especially in offices that use open office layouts to increase collaboration and innovation among employees. Although operationally, this type of layout can increase productivity; however, during a pandemic, it actually increases the chance of transmitting the Covid-19 virus through human interactions (Dietz et al., 2020). The workplace's new configuration must be set with the distance between the workstations is at least two meters. If the distance between the workstations cannot be met, the separator between the workstations from acrylic should be used to shield staff from breathing droplets from others. It can be seen in Figures 11 and 12.

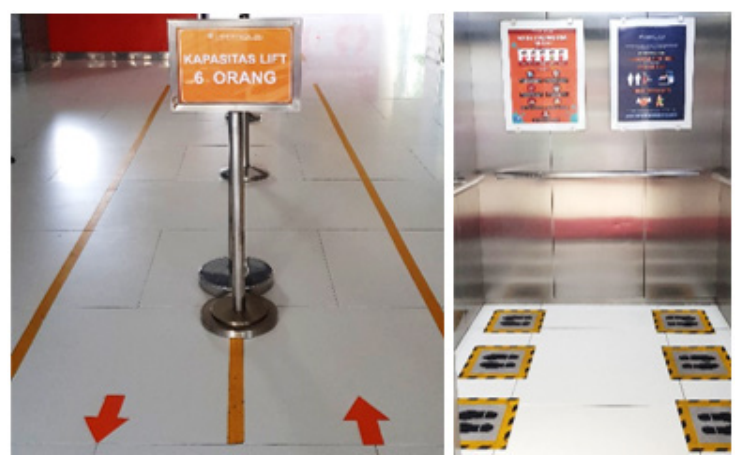

Figure 11 Maintain Social Distancing with Marker Sticker on the Main Circulation

(Source: Personal Documentation, 2020) 


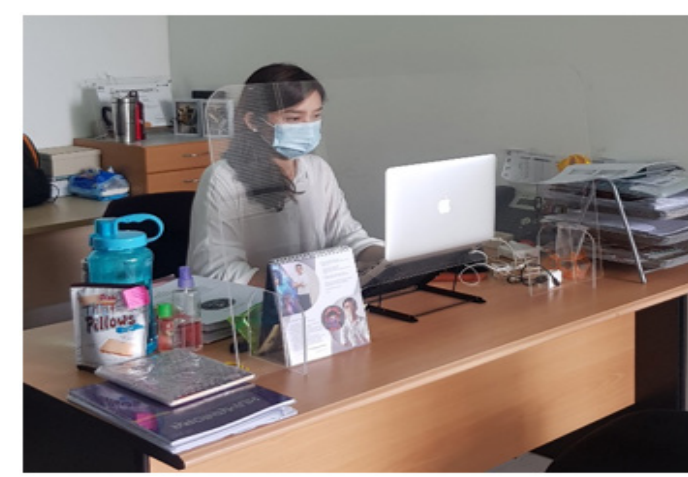

Figure 12 Acrylic Separator to Shield Staff from Breathing Droplets

(Source: Personal Documentation, 2020)

Workplace flexibility needs to be considered, including awareness of work from home and work from the office shift to minimize the number of employees in the building and shortened working hours to reduce the risk of transmission for employees. Besides, reducing face-to-face meetings is also needed by doing virtual interaction as far as possible. Physical meetings need not be stopped, if inevitable, physical meetings should consider recommendations for the social distancing of attendees seated at least two meters apart.

The case study in the Ciputra University workplace illustrates how the new normal is implemented in offices. Based on the findings of the observations, efforts have been done to reduce the spread of the Covid-19 virus in the workplace of Ciputra University by implementing a strategy that is in line with the objectives of IHC 1, IHC 2, and IHC 5. Efforts that are in line with the objectives of other IHC criteria have not been found in the case study but still need to be applied for a better quality of indoor environmental quality and to reduce the spread of the virus more effectively.

\section{CONCLUSIONS}

Adjustment to IHC criteria in IHC 1-10 focuses on providing good air quality by introducing outside air, stopping air recirculation, reducing indoor user capacity, and reducing indoor biological and chemical pollutants. This strategy will minimize the risk of aerosol transmission not only for the current pandemic but also for other airborne infectious diseases. Adjustment of these criteria must be supported by implementing health protocols through basic hygiene routines, fitness screening, and maintaining physical distancing.

The research results are expected to contribute to the workplace criteria in the new normal era with the limitation of the research focused on adjustment in the IHC criteria. Further research that can be done are looking for adjustments' proposal for the new building greenship criteria that not only concern about sustainability but also to health, and reduce the spread of viruses that can be achieved with net zeroand healthy building. One of the strategies through a passive design building strategy is maximizing natural ventilation, such as building orientation for maximum air movement, well-designed openings, and the effective sequence of space conditions and ventilation.

\section{REFERENCES}

Brittain, O. S., Wood, H., \& Kumar, P. (2020). Prioritising indoor air quality in building design can mitigate future airborne viral outbreaks. Cities \& Health, O(0), 1-4. https://doi.org/10.1080/23748834.2020.1 786652.

Cook, T. M. (2020). Personal protective equipment during the COVID-19 pandemic: A reply. Anaesthesia, 75(8), 1121-1122. https://doi.org/10.1111/ anae. 15158 .

Cummings, B. E., \& Waring, M. S. (2020). Potted plants do not improve indoor air quality: A review and analysis of reported VOC removal efficiencies. Journal of Exposure Science \& Environmental Epidemiology, 30(2), 253-261. https://doi.org/10.1038/s41370019-0175-9.

Darus, F. M., Ahmed, A. Z., \& Latif, M. T. (2011). Preliminary assessment of indoor air quality in terrace houses. Health and the Environment Journal, 2(2), 8-14.

Dhand, R., \& Li, J. (2020). Coughs and sneezes: Their role in transmission of respiratory viral iunfections, including SARS-CoV-2. American Journal of Respiratory and Critical Care Medicine, 202(5), 651-659. https://doi.org/10.1164/rccm.202004$1263 p p$.

Dietz, L., Horve, P. F., Coil, D. A., Fretz, M., Eisen, J. A., \& Van Den Wymelenberg, K. (2020). 2019 novel coronavirus (COVID-19) pandemic: Built environment considerations to reduce transmission. MSystems, 5(2), 1-41. https://doi.org/10.1128/ msystems.00245-20.

EPA (United States Environmental Protection Agency). (2009). A brief guide to mold, moisture, and your home. Retrieved from https:/www.epa.gov/sites/ production/files/2016-10/documents/moldguide12. pdf.

Fahimipour, A. K., Hartmann, E. M., Siemens, A., Kline, J., Levin, D. A., Wilson, H., Betancourt-Román, C. M., Brown, G., Fretz, M., Northcutt, D., Siemens, K. N., Huttenhower, C., Green, J. L., \& Van Den Wymelenberg, K. (2018). Daylight exposure modulates bacterial communities associated with household dust 06 Biological Sciences 0605 Microbiology. Microbiome, 6(1), 1-13. https://doi. org/10.1186/s40168-018-0559-4.

Gormley, M., Aspray, T. J., \& Kelly, D.A. (2020). COVID-19: Mitigating transmission via wastewater plumbing systems. The Lancet Global Health, 8(5), e643. https://doi.org/10.1016/S2214-109X(20)30112-1.

Kampf, G., Todt, D., Pfaender, S., \& Steinmann, E. (2020). 
Persistence of coronaviruses on inanimate surfaces and their inactivation with biocidal agents. Journal of Hospital Infection, 104(3), 246-251. https://doi. org/10.1016/j.jhin.2020.01.022.

Kazemi, F., Rabbani, M., \& Jozay, M. (2020). Investigating the plant and air-quality performances of an internal green wall system under hydroponic conditions. Journal of Environmental Management, 275, 111230. https://doi.org/10.1016/j.jenvman.2020.111230.

Khanna, R., Cicinelli, M., Gilbert, S., Honavar, S., \& Murthy, G. (2020). COVID-19 pandemic: Lessons learned and future directions. Indian Journal of Ophthalmology, 68(5), 703-710. https://doi. org/10.4103/ijo.IJO_843_20.

Kumar, P., \& Morawska, L. (2019). Could fighting airborne transmission be the next line of defence against COVID-19 spread? City and Environment Interactions, 4, 1-3. https://doi.org/10.1016/j. cacint.2020.100033.

Lee, Y. S., \& Guerin, D. A. (2010). Indoor environmental quality differences between office types in LEED-certified buildings in the US. Building and Environment, 45(5), 1104-1112. https://doi. org/10.1016/j.buildenv.2009.10.019.

Lim, Y. W., Kandar, M. Z., Ahmad, M. H., Ossen, D. R., \& Abdullah, A. M. (2012). Building façade design for daylighting quality in typical government office building. Building and Environment, 57, 194-204. https://doi.org/10.1016/j.buildenv.2012.04.015.

Marshall, D., Bois, F., Jensen, S. K. S., Linde, S. A., Higby, R., Remy-McCort, Y., Murray, S., Dieckelman, B., \& Sudradjat, F. (2020). Sentinel coronavirus environmental monitoring can contribute to detecting asymptomatic SARS-CoV-2 virus spreaders and can verify effectiveness of workplace COVID-19 controls. Microbial Risk Analysis, 16, 100137. https://doi.org/10.1016/j.mran.2020.100137.

Miller, S. L., Linnes, J., \& Luongo, J. (2013). Ultraviolet germicidal irradiation: Future directions for air disinfection and building applications. Photochemistry and Photobiology, 89(4), 777-781. https://doi.org/10.1111/php.12080.

Morawska, L., Johnson, G. R., Ristovski, Z. D., Hargreaves, M., Mengersen, K., Corbett, S., Chao, C. Y. H., Li, Y., \& Katoshevski, D. (2009). Size distribution and sites of origin of droplets expelled from the human respiratory tract during expiratory activities. Journal of Aerosol Science, 40(3), 256-269. https://doi. org/10.1016/j.jaerosci.2008.11.002.

Morawska, L., \& Cao, J. (2020). Airborne transmission of SARS-CoV-2: The world should face the reality. Environment International, 139, 1-3. https://doi. org/10.1016/j.envint.2020.105730.

Morawska, L., Tang, J. W., Bahnfleth, W., Bluyssen, P. M., Boerstra, A., Buonanno, G., Cao, J., Dancer, S., Floto, A., Franchimon, F., Haworth, C., Hogeling, J., Isaxon, C., Jimenez, J. L., Kurnitski, J., Li, Y., Loomans, M., Marks, G., Marr, L. C., ... Yao, M. (2020). How can airborne transmission of COVID-19 indoors be minimised? Environment International, 142, 1-7. https://doi.org/10.1016/j. envint.2020.105832.

Nasir, R. Y. (2012). GREENSHIP interior space version 1.0. april. Retrieved from http://www.gbcindonesia. org/2012-08-01-03-25-31/2012-08-02-03-43-34/ summary.

Noti, J. D., Blachere, F. M., McMillen, C. M., Lindsley, W. G., Kashon, M. L., Slaughter, D. R., \& Beezhold, D. H. (2013). High humidity leads to loss of infectious influenza virus from simulated coughs. PLoS ONE, 8(2), 2-9. https://doi.org/10.1371/journal. pone. 0057485 .

Rousseau, C. P., Sheerin, M. P., Flannery, J. J., Brown, R. V., Castillo, D. C., Dombrowski, J. M., Erickson, D. S., Fauber, J. P., Friedman, S. D., Granzow, F. E., Gregory, J. S., Hardin, J. M., Herrig, L. B., Hosking, N., Keen, M. R., Kloostra, M. L., Locke, M. D., Mead, K. R., Ninomura, P. T., ... Humble, J. (2017). Ventilation of health care facilities 2017. Retrieved from https://www.ashrae.org/technical-resources/ standards-and-guidelines/standards-addenda/ansiashrae-ashe-standard-170-2017-ventilation-ofhealth-care-facilities.

Salas, J., \& Zafra, M. (2020). An analysis of three COVID-19 outbreaks: How they happened and how they can be avoided. Retrieved from https://english.elpais.com/ spanish_news/2020-06-17/an-analysis-of-threecovid-19-outbreaks-how-they-happened-and-howthey-can-be-avoided.html.

Salingaros, N. A. (2015). Biophilia \& healing environments: Healthy principles for designing the built world. New York: Terrapin Bright Green, LLC.

Setti, L., Passarini, F., De Gennaro, G., Barbieri, P., Perrone, M. G., Borelli, M., Palmisani, J., Di Gilio, A., Piscitelli, P., \& Miani, A. (2020). Airborne transmission route of covid-19: Why 2 meters $/ 6$ feet of inter-personal distance could not be enough. International Journal of Environmental Research and Public Health, 17(8), 1-6. https://doi. org/10.3390/ijerph17082932.

Sundari, T., Lisdawati, V., Jahiroh, Zunaidi, E., Indrawanto, D., Murtiani, F., Yohana., Montain, M. M., Pakki, T. R., \& Rogayah, R. (2018). Peran sistem tata udara dalam pencegahan dan pengendalian infeksi di ruang isolasi airborne RSPI Prof. Dr. Sulianti Saroso tahun 2017. The Indonesian Journal of Infectious Diseases, 4(1), 1-10. https://doi.org/10.32667/ijid. v4i1.56.

Susan, \& Wardhani, D. K. (2019). Enhancing indoor health comfort in adaptively reused heritage building. Proceedings of the Annual International Conference on Architecture and Civil Engineering 2019. Singapore. pp. 228-235.

Tang, S., Mao, Y., Jones, R. M., Tan, Q., Ji, J. S., Li, N., Shen, J., Lv, Y., Pan, L., Ding, P., Wang, X., Wang, Y., MacIntyre, C. R., \& Shi, X. (2020). Aerosol transmission of SARS-CoV-2? Evidence, prevention, and control. Environment International, 144, 1-10. https://doi.org/10.1016/j.envint.2020.106039.

Triandini, E., Jayanatha, S., Indrawan, A., Werla P. G., \& Iswara, B. (2019). Metode systematic literature review untuk identifikasi platform dan metode 
pengembangan sistem informasi di Indonesia. Indonesian Journal of Information Systems, 1(2), 63-77. https://doi.org/10.24002/ijis.v1i2.1916.

Wardhani, D. K., \& Susan. (2019). Greenship assessment of indoor health comfort in adaptive reused building. Proceedings of the Annual International Conference on Architecture and Civil Engineering. Singapore. pp. 236-244. https://doi.org/10.5176/2301-394X ACE19.578.

West, R., Michie, S., Rubin, G. J., \& Amlôt, R. (2020). Applying principles of behaviour change to reduce SARS-CoV-2 transmission. Nature Human Behaviour, 4(5), 451-459. https://doi.org/10.1038/ s41562-020-0887-9.

World Health Organization. (2020). Laboratory biosafety guidance related to coronavirus disease (COVID-19). Interim Guidance, 19, 1-5. https://doi.org/10.1016/j. ccm.2016.11.007.

Wu, F., Zhao, S., Yu, B., Chen, Y. M., Wang, W., Song, Z. G., Hu, Y., Tao, Z. W., Tian, J. H., Pei, Y. Y., Yuan, M. L., Zhang, Y. L., Dai, F. H., Liu, Y., Wang, Q. M., Zheng, J. J., Xu, L., Holmes, E. C., \& Zhang, Y. Z. (2020). A new coronavirus associated with human respiratory disease in China. Nature, 579(7798), 265-269. https://doi.org/10.1038/s41586-020-20083. 